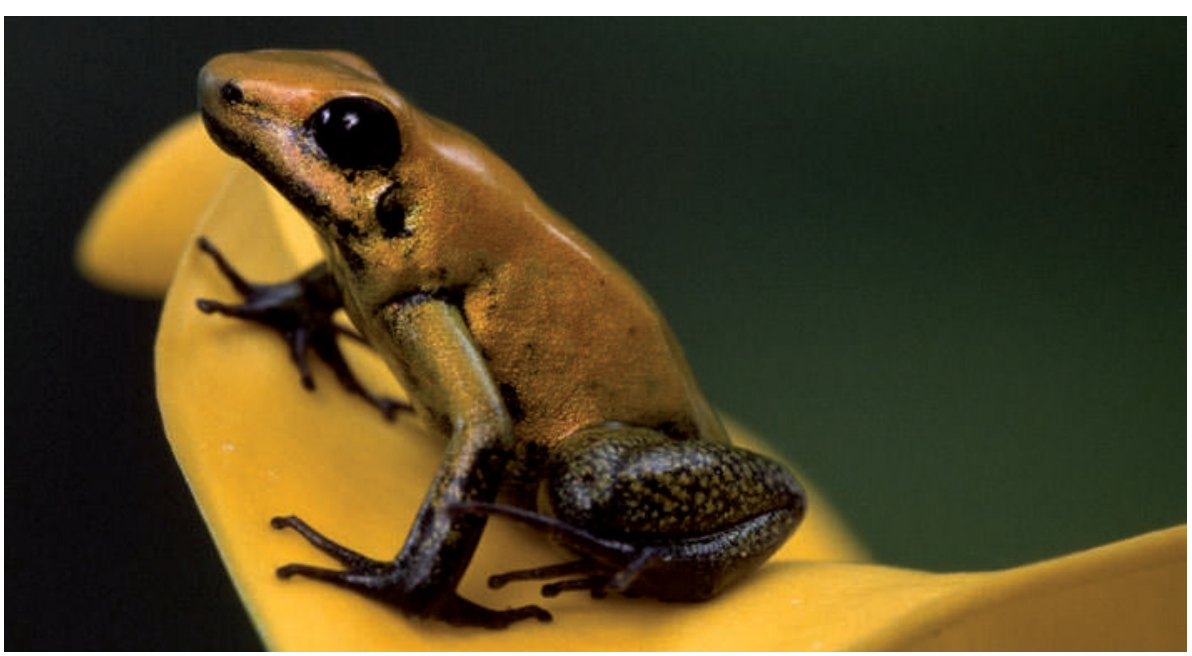

The golden poison frog (Phyllobates terribilis) is one of many endangered amphibian species.

CONSERVATION

\title{
Biodiversity hope faces extinction
}

\section{Upcoming meeting will set out global conservation targets.}

\section{BY NATASHA GILBERT}

$\mathrm{T}$ he future of the world's biodiversity hangs in the balance as countries convene for crucial negotiations next week in Nagoya, Japan. The 193 signatory nations to the Convention on Biological Diversity (CBD) pledged eight years ago to cut species loss "significantly" by this year. But studies show that the health of global biodiversity is reaching a crisis point, with extinctions of mammal and amphibian species continuing to rise (see Nature 462, 263; 2009).

Conservation leaders hope that the meeting of CBD nations on 18-29 October will give the green light to a new set of international agreements to help protect biodiversity. These include 20 new ambitions to be met by 2020 , such as halving the loss and degradation of forests and other natural habitats, and ensuring that agriculture and aquaculture are sustainably managed (see Nature doi:10.1038/news.2010.31;2010).

Agreement on the general ambitions looks likely, but large international rifts over conservation funding and access to the genetic resources of ecologically rich nations are threatening to derail the negotiations over how to achieve them. Failure to reach agreement could be a severe setback for international efforts to save biodiversity, says Jane Smart, director of biodiversity conservation at the International Union for Conservation of Nature, headquartered in Gland, Switzerland. "It all comes down to what happens at Nagoya," she says. "If it does not succeed, rebuilding morale and momentum will be such a big mountain to climb."

A lack of money for conservation projects is a key reason why governments have failed to meet their 2010 targets, says a spokesman for the CBD. For example, the 33 member nations of the Organisation for Economic Co-opera-

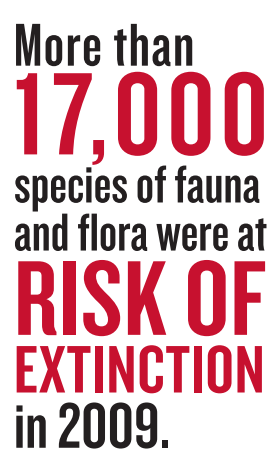
tion and Development donated US $\$ 8.5$ billion for climate-change mitigation projects in 2008 , but only $\$ 3$ billion annually for biodiversity.

Several proposals for mustering funds are up for discussion next week. The billiondollar budget for the Global Environment Facility - an international partnership used by wealthy countries, businesses and other stakeholders to fund biodiversity projects - could be doubled, for example. Japan is expected to use the meeting to announce a trust fund for biodiversity, says Ahmed Djoghlaf, executive secretary of the CBD. "I hope Europe will do the same," he says. But Djoghlaf declined to say how much money he would like donors to pledge. "It's not a figure we are looking for, but an approach."

One fund-raising mechanism gaining support is the phasing out of subsidies that are

harmful to biodiversity. For example, global subsidies to marine fisheries are estimated at around $\$ 15$ billion- $\$ 35$ billion annually, according to 2008 figures from the United Nations Environment Programme. The Food and Agriculture Organization of the United Nations says that fish stocks in almost onethird of these fisheries are close to collapse or have already done so.

"If we cut subsidies, this will free up a lot of funds that can be put back into protecting fisheries," says Lina Barrera, director of biodiversity and ecosystem services at Conservation International, a non-profit green group based in Washington DC. Barrera is optimistic that the proposal to cut subsidies will be approved, because it has come through premeeting negotiations "relatively unscathed".

But there is likely to be tense debate on a proposed legally binding agreement to tighten rules for access to nations' genetic resources, such as plants that potentially produce pharmaceuticals. Biodiversity-rich countries, which are typically in the developing world, are concerned that the access and benefits scheme that has been pro-

Over half of all MEDICINAL PLANTS in Africa face EXTINCTION. posed is not strong enough to guarantee them financial compensation if their resources are developed into commercial products by foreign companies, which are often based in developed nations. "The wording is very ambiguous. Some countries feel they could be making resources available on terms that are not good for them, and that they could be giving up their profits," says Geoff Burton, an expert on biodiversity law at the United Nations University Institute of Advanced Studies in Yokohama, Japan.

Developing countries want the rules to cover products that have been generated in the past, but companies and developed countries say that only products worked on after the regulations are legally implemented should be affected. However, the scheme could give basic researchers easier access to genetic resources: earlier this year, negotiators reached a broad agreement that non-commercial research should not be inhibited by any future rules (see page 779 ).

Burton is concerned that failure to reach agreement on the more contentious aspects of the rules could derail the non-commercial exemption before it is signed by all the parties. But Djoghlaf is optimistic that countries will agree to a set of core principles, and then set a timetable for hammering out the finer details

$\rightarrow$ NATURE.COM For breaking news from the Nagoya summit, see: nature.com/news by 2012. "I can't imagine closing the meeting without agreement on the access and benefit sharing scheme," he says. - SEEEDITORIALP.752 